\title{
Some Critical Thinking on Paulo Freire's Critical Pedagogy and Its Educational Implications
}

\author{
Yi-Huang Shih ${ }^{1}$ \\ ${ }^{1}$ Department of Early Childhood Educare, Ching Kuo Institute of Management and Health, Keelung, Taiwan \\ Correspondence: Yi-Huang Shih, Department of Early Childhood Educare, Ching Kuo Institute of Management \\ and Health, Keelung, Taiwan. Tel: 88-62-2437-2093. E-mail: shih262@gmail.com
}

Received: April 25, 2018

Accepted: June 10, $2018 \quad$ Online Published: August 28, 2018

doi:10.5539/ies.v11n9p64

URL: https://doi.org/10.5539/ies.v11n9p64

\begin{abstract}
Through critical interpretation, this paper aims to critically think about some points of Paulo Freire's critical pedagogy and its educational implications. Firstly, this paper explores the influence of life experiences and the Frankfort School on the development of Freire's critical pedagogy. Secondly, it aims to critically assess some points of Freire's critical pedagogy, and illuminate their educational implications. The following points of his critical pedagogy are included: (1) education as the practice of freedom, and (2) dialogue, problem-posing education and conscientization. It is hoped that such an exploration can bring some inspiration to education, and benefit the development of education.
\end{abstract}

Keywords: conscientization, dialogue, Frankfort School, freedom, Paulo Freire

\section{Introduction}

Paulo Reglus Neves Freire (1921-1997) is surely one of the most cited and iconic figures in the contemporary education literature (Mayo, 2014). Freire is an influential philosopher and politician (Saleh, 2013), and is one of the most significant educators in the world during the 20th century. Freire is seen as a new kind of intellectual, and is described as "organic" in the words of Gramsci. In August 1986, the New York Times published an article which stressed the importance of Freire in the organization of various educational systems (Gadotti, 1994). In addition, Torres described the use of Freire's critical pedagogy in social studies, curriculum studies, adult education, secondary education, higher education, and educational planning (Saleh, 2013). Based on the above description, we can see the influence of Freire's critical pedagogy on contemporary education. The life experiences and the Frankfort School influenced the development of Freire's critical pedagogy, and thus this paper first explores the above argument.

Freire wanted teachers to treat learners as co-creators of knowledge. According to the problem-posing method, particular attention is drawn to the dialogue, in the course of which everyone can ask questions or express his/her own views freely (Duchak, 2014). Therefore, education is seen as the practice of freedom, and in the practice of freedom, through the dialogue, teachers and students can raise their awareness. Freire argues that education requires questioning as the core of the dialogue, and the possibility of questioning is included in the dialectical structure of dialogue topics. Furthermore, the presentation of the issues of the dialogue must seek questionable questions from the life situation of the teachers (Wang, 1990).

This paper aims to critically address some points of Freire's critical pedagogy and their educational implications. Firstly, we explore the influence of life experiences and the Frankfort School on Freire's critical pedagogy. Secondly, this paper aims to critically think about some points of his critical pedagogy, and illuminate educational implications for contemporary education. The following points are included: (1) education as the practice of freedom, and (2) dialogue, problem-posing education and conscientization.

\section{Research Method}

This study uses the method of critical interpretation. Those of us interested in the connotation of Freire's critical pedagogy can clearly see that Freire uses "criticism" as a tool for emancipation. Moreover, people are thought of as being associated with their living world in a critical way (Freire, 2000; Gadotti, 1994). Because of this, we can see the importance of "criticism" in Freire's critical pedagogy. This study attempts to use critical hermeneutic method to understand Freire's critical pedagogy. 


\section{The Influence of Life Experiences on Freire's Critical Pedagogy}

By analyzing Brazil's social background, one can understand the situation of Brazil's society where Freire lived. In politics, it was an autocratic dictatorship, where power is concentrated in a small number of elites. Economically, the gap between the rich and the poor was huge. The poor suffered from poverty and hunger; and social class was clearly polarized. In education, the quality and quantity of education were insufficient, the illiteracy rate was high, and the level of education was low. Religious belief was influenced by liberation theology. Within this context, Freire hoped to free the oppressed. However, the vast majority of people in Brazil lived in "ignorance" and in a "silent culture." They could not view the world they lived in with critical vision. They could not perceive the entire structure of oppression and the contradictory nature of Brazilian society. Therefore, they could not construct a free and humane society. Freire lived in this social context and hoped to awaken the critical consciousness of the oppressed, thus shaping his idea of critical pedagogy. Freire hoped to transform F. Fanon's so-called "wretched of the earth". They could change from "being for others" to "being for themselves" (Freire, 1985; Macedo, 2000).

\section{The Influence of the Frankfort School on Freire's Critical Pedagogy}

\subsection{Critical Pedagogy Is a Relatively Old Concept, Primarily Uncovered by Freire}

Critical pedagogy is a relatively old concept, primarily uncovered by Freire in his book titled "The Pedagogy of the Oppressed in the 1960s and 70s" (Riasati \& Mollaei, 2012).

Freire's problem-posing education endeavored for empowerment as a goal of education and he criticized traditional education viewing learners as empty agents (Riasati \& Mollaei, 2012).

\subsection{Critical Pedagogy Is Rooted in the Notion That Education Should Play a Role in Creating a Just and Democratic Society}

Critical pedagogy is deeply rooted in the notion that education should play a role in creating a just and democratic society (Nouri \& Sajjadi, 2014). While pedagogy is most simply conceived of as the study of teaching and learning, the term critical pedagogy embodies notions of how one teaches, what is being taught, and how one learns. Freire is regarded as the inaugural philosopher of critical pedagogy for his work on recognizing the relationships among education, politics, imperialism, and liberation (Breunig, 2005).

\subsection{Freire's Critical Pedagogy Has Been Influenced by the Frankfort School}

Critical pedagogy is a reflection of the Frankfort School's ideas and principles in education. Critical theory was initially started in Europe and was then developed by theorists such as Habermas, Horkheimer, Adorno, and Gramsci. The emergence of the Frankfort School is marked with the formation of the Institute for Social Research at Frankfort University in 1923. And Freire's critical pedagogy, which has been influenced by the Frankfort School, has introduced a new approach to contemporary educational issues (Mahmoudi, Khoshnood \& Babaei, 2014).

\section{Some Thinking on Paulo Freire's Critical Pedagogy}

\subsection{Education as the Practice of Freedom}

\subsubsection{Freire Paid Attention to Issues of Freedom and Authority in Education}

Issues of freedom need attention in the practice of education, so Freire paid attention to issues of freedom and authority in education. The most interesting argument of Freire is his addressing of the tension between freedom and authority and his argument for seeking a balanced approach through which both could be respected. On one hand, Freire perceived "education as the practice of freedom". On the other hand, he emphasized the necessity of establishing limits to this freedom. Freire stressed "freedom" does not mean that there is no limit. He claimed the possibility of joining freedom with authority because separating them leads to the infraction of one or the other (Saleh, 2013; Freire, 1997, 2000). Further, since ancient times, the pursuit of freedom is one of the human nature. When people explore Freire's critical pedagogy- the "Pedagogy of the Oppressed," "Pedagogy of Hope," and "Pedagogy of Freedom," their connotation is ultimately emancipation and freedom. Therefore, in terms of education, "freedom" should be its ultimate concern (Feng, 2004).

\subsubsection{Education for Liberation}

Freire's main concern is how to educate people to emancipate themselves from the culture of silence and to meet the needs of humanity and to develop a more just society (Taylor, 1993). Of course, this emancipatory education method is conscientious, and hopes to use this educational method as the basis for helping individuals to awaken their own critical consciousness, and then take a more critical view of social reality to obtain liberation. For this reason, Freire's liberation of education can change people's perception of external reality (Shor \& Freire, 1987), 
making individuals more critical and more autonomous. After all, if people attribute facts to supernatural powers, they view the cause and effect of things in a simplified way. In this process, God, destiny, and luck often play important roles. If people's interpretation of the living situation is only based on supernatural power, or on their own incompetence, they tend to rely on God to act and deny that man and God can change reality. It is obvious that in this case their actions will not be able to transform external reality (Freire, 1985; Smith, 1976).

Freire's critical pedagogy focuses on the struggle for the liberation of the poor. He advocated "education for liberation." Freire rejected the banking method. The banking education thus becomes an act of depositing, in which the students are the depositories and the teacher is the depositor Instead of communicating. This is the "banking" concept of education, in which the scope of action allowed to the students extends only as far as receiving, filing,and storing the deposits. They do, it is true, have the opportunity to become collectors or cataloguers of the things they store. But in the last analysis, it is the people themselves who are filed away through the lack of creativity, transformation, and knowledge in this (at best) misguided system. For apart from inquiry, apart from the praxis, individuals cannot be truly human. Knowledge emerges only through invention and re-invention, through the restless, impatient, continuing, hopeful inquiry human beings pursue in the world, with the world, and with each other (Freire, 2000).

The banking method of teaching/learning which he believed minimized the learners' ability to think critically. He proposed the problem-posing/problem solving method as he believed this would help learners to think critically and challenge the world (Emily, 2014). Freire stressed that education is the practice of freedom (Freire, 1997).

Liberal education often challenges domination by exposing the irrationality of life's reality (Shor \& Freire, 1987).

Furthermore, as far as liberation is concerned, individuals will not be liberated if they are dominated. Therefore, in the current educational practice, if education is not for the aim of liberation and it is difficult for students to liberate themselves. So education must be an activity for liberation.

\subsubsection{Transforming and Improving the Education Situation of Oppression}

In the process of awakening the individual consciousness, transforming and improving the situation of oppression in education becomes extremely important. Freire (2000, p. 64) pointed out that when the oppressive situation improves, people can find that the "self-deprecating" situation of the oppressed shows surprising improvement. That is, the individual's consciousness gradually increases, and gradually they are able to perceive the living world. In the context of oppression, the oppressed cannot be conscious of awakening. In other words, when the oppressed are in an oppressive situation, they are less conscious of awakening.

\subsection{Dialogue, Problem-Posing Education and Conscientization}

\subsubsection{Genuine Dialogue Represents a Form of Humanizing Praxis}

In Freire's moral philosophy, praxis and dialogue are closely related: genuine dialogue represents a form of humanizing praxis. Dialogue is "the encounter between men, mediated by the world, in order to name the world" (Roberts, 2000). In order to enable teachers and students to maintain their own intentionality and become an interactive or communicative subject coexisting with the external world or others, Freire advocated that teachers and students should have equal dialogue, instead of teachers with absolute authority to oppress students. Teachers should use equal and interactive dialogues and mutual respect with students based on intersubjectivity. Thus, students are with the courage and ability of "critical consciousness" (Yang-Wang, 2010).

Education must be democratic and dialogical. Freire emphasized the importance of dialogue between teachers and students. The various elements of dialogue include love, humility, hope, faith and critical thinking (Freire, 2000).

\subsubsection{Freire's Problem-Posing Education Strived for Empowerment as an Aim of Education}

Freire's critical pedagogy relates to the critical or radical education. Freire promoted critical literacy skills among socially oppressed Brazilian farmers, and preached the ways in which education can give people tools to construct better lives and to participate more fully in determining their own destinies. Freire's problem-posing education strived for empowerment as an aim of education (Ooiwa-Yoshizawa, 2018).

\subsubsection{Freire's Literacy Method Based on Conscientization and Dialogue}

In simple terms, conscientization may be defined as the critical awareness of reality and the capacity to transform it (Nyirenda, 2018). In Yep's research, using Freire's notions of conscientization, dialogue, and liberation, the author reflects on how he has engaged a student-centered dialogue in his teaching in general and in discussions of sexism, heterosexism, homophobia, and transphobia in particular. More specifically, he examines how this dialogic process enables his students and himself to (re)discover ways in which they can liberate themselves by exposing normalizing discourses and dominant ideologies, examining the relationship between oppressor and 
oppressed, shifting from object to subject positions, and (re)negotiating power relations (Yep, 1998).

\section{Implications for Education}

\subsection{The Individual Can Be in Dialogue with the Other Person in a Critical Vision.}

"Instruction" is the core of educational practice. "Instruction" includes teaching and learning. It is a subject that education practice must face. However, the essence of teaching and learning should be dialogic. Because there is no dialogue, there is no communication. Without communication, there can be no real education. There can be no real teaching and learning (Berthoff, 1987; Freire, 2000).

Freire thinks that people cannot exist without their ideals (Freire, 1998), and firmly believes that no matter how "ignorant" the individual is, or how "silent" the "culture" is where the individual lives, he can also be in dialogue with the other person in a critical vision. If an appropriate tool is provided in a dialogue with another person, the individual will be able to gradually perceive the contradiction between himself and the society, be aware of the state of the world he is in, and, thus, able to handle it with a critical attitude (Shaull, 1993). The appropriate tool is provided in a dialogue; as such, teachers must develop the educational practice of freedom.

\subsection{Practicing Freedom-Based Educational Practice}

\subsubsection{There Seems to Be a Fundamental Need or Longing in Human Beings to be "Free"}

From a general point of view, "freedom" refers to "a state in which an individual is unconstrained." This constraint may come from its own destiny, or from the constraints of the external living environment. As far as philosophical point of view is concerned, there are different references to the meaning of "freedom." One of them thinks that "freedom" refers to the ability of an individual to choose something without choosing something according to his or her will. From the Civil Rights Movement led by Martin Luther King, to the recent Arab Spring Movement, freedom has been repeatedly used in history as an effective clarion call to rally the masses to collective action. At the same time, freedom or liberty has been enshrined as one of the fundamental values of many modern nation states. Hence, there seems to be a fundamental need or longing in human beings to be "free" (Lee, 2016).

\subsubsection{Teachers Must Understand the Methods of Manifesting Freedom in Education}

Freire stressed that education as the practice of freedom, and education should be an activity of freedom (Freire, 1997). So teachers must understand the methods of manifesting freedom in education. For this reason, in order to help teachers comprehend how to manifesting freedom of students in education, the author suggests that teachers practice dialogue and problem-posing education. Through dialogue and problem-posing, teachers and students are engaged in a practice of listening to different perspectives, and naming and transforming the world. Teachers and students can empower themselves. Further, through dialogue and problem-posing, the freedom of students manifests. The methods of manifesting the freedom of students include: (1) developing education that "dematerializes" students, (2) practicing "non-dogmatic" education, and (3) the creation of a "free" atmosphere in the educational environment, (4) students have the opportunity to choose their mode of existence, (5) respecting the human rights of students' self-determination, and (6) respecting students' autonomy. Based on the abovementioned methods, the image of humanizing education can be formed. Above all, through the humanizing praxis of education, teachers can practice freedom-based educational practice, teachers and students can promote their critical awareness of reality and the capacity to transform it (Shih, 2013).

So in the teaching of teachers, it is necessary to integrate the concept of questioning education, use question-based education methods, present students' living situations, ask students questions, and allow them to think dialectically. As far as the nature of teaching is concerned, teaching is a profession (Smith, 1969), a meaningful value activity constructed by the previous generation and the next generation. In this kind of value activity centered on "students", it is necessary to create a teaching situation that cultivates free individuals (Green, 1969). This teaching situation is of course an opportunity for children to have self-selection and decision-making.

\subsection{Curriculum Planning Is a Fully People-Oriented Process}

Curriculum is often seen as a combination of the different learning experiences of students and the meaning of learning. As such, the courses taught by the school should be the subject of our concern. For the purpose of education, which is usually to hope that the individual being taught can be self-aware and self-realize through the course of education. Therefore, these general educational purposes are often divided into six aspects, including The Transcendent Self, The Aesthetic Self, The Physical Self, The Social Self, The Emotional Self, and The Intellectual Self, all of which are attached to the purpose of courses and practiced through courses (Foshay, 2000). That is to say, the professors of the school curriculum allow the educated to perceive their physical condition, how they interact with others (the coping of interpersonal relationships), their own emotions, and even the educated 
people's intellectual growth, even can enhance their own aesthetic judgment, and then self-transcendence. Therefore, teachers should think about how to let students achieve the above educational goals when designing the curriculum. In addition, curriculum development as an approach asks questions such as: "What are the elements of curriculum planning? What steps should one follow in planning a curriculum (Preez \& Simmonds, 2014)?" From Freire's perspective, curriculum planning is a fully people-oriented process in which the starting point is people and their expectations and wants. He believes that curriculum planning is an ongoing process which can be done through mutual participation of teachers and students. Based on this perspective, curriculum planning is not a top-down process and all the people who are involved in the education and learning process should play their role in educational planning (Mahmoudi, Khoshnood, \& Babaei, 2014). In Williams's teaching, following Freire, "Cultural Circles" establish their own learning units by engaging in a dialogue that results in the development of the learning units of interest (Williams, 2009). In the planning of a "Cypher", teachers pose a question to the participants, such as: "What problems do you see in Hip Hop today?" This would be the last formal question that teachers would ask of the students (Williams, 2009). This curriculum planning is a fully people-oriented process.

\section{Conclusion}

Garaudy, a famous philosopher and writer, points out that Freire's writings can serve as a motive force for people to complete social reconstruction (Gadotti, 1994). In fact, Freire's books give people a language of life. They make people think deeply about the construction of resistance in self-identity (Hooks, 1993). Freire's writings in Brazil and Chile have virtually inflected the oppressed people. His writings have also affected the educational practices in Latin America and Africa. They have created new hopes for future life, and provided them with new hope. His writings liberated and educated themselves (Haviland, 1973; Torres, 1993).

For Freire, the opposite of humanity is dehumanization (or oppression), and the situation of oppression is a so-called "culture of silence", which can be regarded as the appearance of Brazilian history and culture. The culture of silence comes from ignorance. Freire believed that assimilation of tenants in poor social systems is a form of oppressive education (Elias \& Merriam, 1995; Freire, 1985).

Freire believed that critical pedagogy involves both the recognition that human life is conditioned, not determined, and the crucial necessity of not only reading the world critically but also intervening in the larger social order as part of the responsibility of an informed citizenry (Giroux, 2010). To challenge the banking education model, Freire proposed problem-posing education (Rugut \& Osman, 2013). His ideas are on empowering and democratizing education (Saleh, 2013).

Freire addressed the education system through proposing a methodology (problem-posing education); contrasted with the traditional authoritarian approach (banking education) (Saleh, 2013). In this education model (problem-posing education), the teacher and learner discuss and analyze their experiences, feelings and knowledge of the world together (Rugut \& Osman, 2013). Education is a liberating practice, because reform itself is an educational task, and educators are the politicians. The critical thinking that liberation education wants to achieve requires individuals to change their attitudes, awareness, and beliefs. To criticize and question the affair that is taken for granted (Lee, 2003). This problem-posing education attempts to make students critical thinkers (Freire, 2000), focusing on the exposure of students' consciousness and critically intervening in the world in which they live. In other words, in this education, the educators can expose their critical consciousness, unlike banking education, which constrains people.

Freire argued that education needs to be viewed as a cultural forum, for which teachers need to possess the cultural-critique ability that frees them the constraints of social values so as to construct a democratic dialogue context in which students are free to express their own cultural experiences and viewpoints. Such a context is able to help students develop independent and critical values, functioning to move society toward democracy (Chiang, 2010).

This paper aims to critically think some educational points of Freire's critical pedagogy and its educational implications. The educational implications are as follows: (1) The individual can be in dialogue with the other person in a critical vision, (2) Practicing freedom-based educational practice. Teachers must not hold grudges when a student disagrees or criticizes or questions critically in the classroom. Teachers should stay open and active and convey messages or grievances to students freely (Mehta \& Pandya, 2016), (3) Curriculum planning is a fully people-oriented process. Curriculum is often one of the main concerns in the educational field. What kind of curricula should we offer to learners? Educators and teachers are concerned about what choices are made during curriculum planning ( $\mathrm{Su}, 2012$ ). Most importantly, curriculum planning should be a fully people-oriented process.

In the educational practice, when the child has the ability to think critically, it is only in the future that they will be able to transform the oppressive world. In fact, when teachers' teaching activity allows students to voice their 
opinion, the teacher's teaching horizon will not be able to blend in with the students' learning horizon, and then present a monologue of teaching, presenting a monologue of teacher-student relationship. Finally, it is hoped that the above exploration can bring some inspiration and benefit to the development of education.

\section{References}

Berthoff, A. E. (1987). Foreword. In P. Freire, \& D. Macedo (Ed.), Literacy: Reading the word and the world (pp. xv-xxvii). London, UK: Routledge \& Kegan Paul.

Breunig, M. (2005). Turning experiential education and critical pedagogy theory into praxis. Journal of Experiential Education, 28(2), 106-123. https://doi.org/10.1177/105382590502800205

Chiang, T. H. (2010). The notions of critical pedagogy and their implications for teacher-pupil interactions. Educational Resources and research, 95, 1-26.

Elias, J. L., \& Merriam, S. B. (1995). Philosophical foundations of adult education. Malabar, FL: Krieger.

Emily, T. (2014). Paulo Freire's education for freedom: Implications for teaching-learning process in Botswana. National Teacher Education Journal, 7(1), 31-36.

Fong, C.-L. (2004). Camel, lion, and child-Transfiguration by Nietzsche, on the origin of critical and alternative pedagogy. Journal of Education Research, 121, 5-13.

Foshay, A. M. (2000). The curriculum: Purpose, substance, practice. New York, NY: Teachers College, Columbia University.

Freire, P. (1985). The politics of education: Culture, power, and liberation. South Hadley, MA: Bergin \& Garvey. https://doi.org/10.1007/978-1-349-17771-4

Freire, P. (1997). Education for critical consciousness (M. B. Ramos, Trans.). New York, NY: The Continuum. (Original work published 1969).

Freire, P. (1998). Politics and education (P. L. Wong, Trans.). Los Angeles, CA: University of California (Original work published 1998).

Freire, P. (2000). Pedagogy of the oppressed (M. B. Ramos, Trans.). New York, NY: The Continuum (Original work published 1968).

Freire, P. (2001). Pedagogy of freedom: Ethics, democracy, and civic courage (P. Clarke, Trans.). Lanham, MD: Rowman \& Littlefield (Original work published 1998).

Gadotti, M. (1994). Reading Paulo Freire: His life and work. Albany, NY: State University of New York Press.

Giroux, H. A. (2010). Rethinking education as the practice of freedom: Paulo Freire and the promise of critical pedagogy. Policy Futures in Education, 8(6), 715-721. https://doi.org/10.2304/pfie.2010.8.6.715

Green, T. F. (1969). A topology of the theaching concept. In C. J. B. Macmillan, \& T. W. Nelson (Eds.), Concepts of teaching (pp. 28-62). Chicago, IL: Rand McNally \& Company.

Haviland, R. (1973). An introduction to the writtings of Paulo Freire. Adult Education, 45(5), 280-285.

Hooks, B. (1993). Bell Hooks speaking about Paulo Freire-The man, his work. In P. McLaren, \& P. Leonard (Eds.), Paulo Freire: A critical encounter (pp. 146-154). London: Routledge. https://doi.org/10.4324/9780203420263_chapter_7

Lee, F.-J. (2003). P. Freire's critical pedagogy and its implications for teachers implementing educational reforms in Taiwan. Bulletin of Educational Research, 49(3), 1-30.

Lee, L. N. (2016). Freedom and morality: Exploring the effects of choice and autonomy on moral attitudes (Unpublished doctoral dissertation). Singapore: National University of Singapore.

Macedo, D. (2000). Foreword. In P. Freire (Ed.), Pedagogy of the oppressed (pp. 11-27). New York, NY: The Continuum.

Mahmoudi, A., Khoshnood, A., \& Babaei, A. (2014). Paulo Freire critical pedagogy and its implications in curriculum planning. Journal of Education and Practice, 5(4), 86-93.

Mayo, P. (2014). Paulo Freire, globalisation and emancipatory education. Andragoške studije, 2, 21-38.

Mehta, S. U., \& Pandya, S. (2016). Paulo Freire's theory: Implications for transformative pedagogy in the Indian context. EduInspire: An International E-Journal, 3(2), 1-26.

Nouri, A., \& Sajjadi, S. M. (2014). Emancipatory pedagogy in practice: Aims, principles and curriculum 
orientation. International Journal of Critical Pedagogy, 5(2), 76-87.

Nyirenda, J. E. (2018). The relevance of Paulo Freire's contributions to education and development in present day Africa. Retrieved February 2, 2018, from http://archive.lib.msu.edu/DMC/African\%20Journals/pdfs/ Africa\%20media\%20review/vol10no1/jamr010001002.pdf

Ooiwa-Yoshizawa, A. (2018). Implications of EFL critical pedagogy: Theory, practice and possibility.

Preez, P. D., \& Simmonds, S. (2014). Curriculum, curriculum development, curriculum studies? Problematising theoretical ambiguities in doctoral theses in the education field. South African Journal of Education, 34(2), 1-14. https://doi.org/10.15700/201412071140

Riasati, M. J., \& Mollaei, F. (2012). Critical Pedagogy and Language Learning. International Journal of Humanities and Social Science, 2(21), 223-229.

Roberts, P. (2000). Education, literacy, and humanization: Exploring the work of Paulo Freire. London, England: Bergin \& Garvey.

Rugut, E. J., \& Osman, A. A. (2013). Reflection on Paulo Freire and Classroom Relevance. American International Journal of Social Science, 2(2), 23-28.

Saleh, S. E. (2013). Paulo Freire's philosophy on contemporary education. University Bulletin, 15(1), 91-111.

Shaull, R. (1993). Foreword. In P. Freire (Ed.), Pedagogy of the oppressed (pp. 11-16). New York: The Continuum.

Shih, Y. H. (2013). Exploring the methods of appearing the freedom and autonomy of students in moral education. Educational Journal of Nhcue, 30(2), 1-27.

Shor, I., \& Freire, P. (1987). A pedagogy for liberation: Dialogues on transforming education. South Hadley, MA: Bergin \& Garvey.

Smith, B. O. (1969). A concept of teaching. In C. J. B. Macmillan, \& T. W. Nelson (Eds.), Concepts of teaching (pp. 11-16). Chicago, IL: Rand McNally \& Company.

Smith, W. A. (1976). The meaning of conscientizacao: The goal of Paulo Freire's pedagogy. Amherst, MA: Center for International Education.

$\mathrm{Su}, \mathrm{S}$. W. (2012). The various concepts of curriculum and the factors involved in curricula-making. Journal of Language Teaching and Research. 3(1), 153-158. https://doi.org/10.4304/j1tr.3.1.153-158

Taylor, P. A. (1993). The texts of Paulo Freire. Philadelphia, PA: Open University Press.

Torres, C. A. (1993). From the pedagogy of the oppressed to a luta continua: The political pedagogy of Paul Freire. In P. McLaren, \& P. Leonard (Eds.), Paulo Freire: A critical encounter (pp. 119-145). London, England: Routledge. https://doi.org/10.4324/9780203420263_chapter_6

Wang, C.-R. (1990). A study on critical adult teaching mode of Paulo Freire (Unpublished doctoral dissertation). National Taiwan Normal University, Taipei.

Williams, A. D. (2009). The critical cultural cypher: Remaking Paulo Freire's cultural circles using Hip Hop culture. International Journal of Critical Pedagogy, 2(1), 1-29.

Yang Wang, C. R. (2010). The humble educator: The critical review of educational courage and wisdom of Paulo Freire. Formosan Education and Society, 20, 145-159.

Yep, G. A. (1998). Freire's conscientization, dialogue, and liberation: Personal reflections on classroom discussions of marginality. International Journal of Sexuality and Gender Studies, 3(2), 159-166. https://doi.org/10.1023/A:1023200612260

\section{Copyrights}

Copyright for this article is retained by the author(s), with first publication rights granted to the journal.

This is an open-access article distributed under the terms and conditions of the Creative Commons Attribution license (http://creativecommons.org/licenses/by/4.0/). 